\title{
The Use of Carbon and Nitrogen Stable Isotopes for the Detection of Poultry Offal Meal in Meat- Type Quail Feeds
}

\section{-Author(s)}

Sernagiotto $E R^{1}$

Ducatti $\mathrm{C}^{2}$

Sartori $\mathrm{JR}^{3}$

Stradiotti $\mathrm{AC}^{4}$

Maruno $\mathrm{MK}^{4}$

Araujo $\mathrm{PC}^{4}$

Carvalho $\mathrm{FB}^{5}$

Pezzato $\mathrm{AC}^{3}$

\section{Animal scientist}

Ass. Prof., PhD, Department of Physics and Biophysics, IBB/UNESP, Botucatu, SP, Brazil

3 Ass. Prof., PhD, Department of Genetic Improvement and Animal Nutrition, FMVZ/ UNESP, Botucatu, SP, Brazil

4 Post-graduation students in Animal Science, FMVZ/UNESP, Botucatu, SP, Brazil

5 Post-graduation student in Animal Science, EVZ, UFG, Goiânia, GO, Brazil

\section{Mail Adress}

Corresponding author e-mail address Ana Cristina Stradiotti - Universidade Estadual Paulista "Júlio de Mesquita Filho", Faculdade de Medicina Veterinária e Zootecnia, Departamento de Melhoramento e Nutrição Animal. Distrito de Rubião Júnior, s/n. Caixa Postal 560. CEP: 18.618-000. Botucatu, São Paulo, Brazil. +55-14- 3880-2998 ana.stradiotti@hotmail.com

\section{"Keywords}

Carbon-13, quail production, stable isotopes, nitrogen-15, traceability.

\section{ABSTRACT}

The objective of the present study was to trace the inclusion of poultry offal meal (POM) in the diet of meat-type quails reared for a long period using the technique of stable isotopes. A number of 320 quails were randomly distributed into eight treatments: vegetable diet (T1), and a diet containing 8\% POM were fed until the end of the experimental period (T2) or replaced by the vegetable diet on day 42 (T3), 56 (T4), 70 (T5), 84 (T6), 98 (T7), and 112 (T8). Breast muscle samples were collected from four birds randomly selected per treatment every 14 days. The obtained isotope results were submitted to multivariate analysis of variance (MANOVA) with the aid of the GLM procedure of statistical SAS program. Treatments were different from T1 when birds were sacrificed at least two weeks after the diet was changed. $\mathrm{T} 2$ results were different from $\mathrm{T} 1$ in all evaluated periods. It was concluded that it is possible to trace poultry offal meal inclusion in a strictly vegetable diet after the diet was changed for at least 14 days.

\section{INTRODUCTION}

Quail meat production has globally increased and it is an interesting option for poultry producers, as quails are able to transform common feedstuffs in a high-quality protein source for human consumption (Baumgartner, 1994). In addition, quail meat presents pleasant flavor and appearance, and it is easy to store.

The number of quails reared in Brazil was approximately 6.2 million in 2002, and has constantly increased thereafter, with an estimated production of 14.68 million in 2010. Two main varieties are reared: Japanese quails (Coturnix coturnix japonica), exclusively used for egg production and the common quail (Cortunix coturnix coturnix), used both for egg and meat egg production. Quails are produced in Brazil almost exclusively for egg production. Approximately $28 \%$ of the eggs are consumed as preserved eggs, $71 \%$ fresh, and only $1 \%$ in other forms (Bertechini, 2010).

The increasing demand for product quality has made farmers and food processing companies to rethink their production systems in order to offer provenly safe products to their customers. Food scares in the 1990s related to bovine spongiform encephalopathy (BSE), foot-andmouth disease cases and the avian flu outbreak in Asia contributed to the adoption of more stringent food safety measures (Gottmann, 2010).

Traceability systems have been implemented to try to ensure the safety of animal products to the consumers in response to the requirements imposed by the European Union in Chapter II, section I, article 11 of the CE regulation n. 1069/2009 of the European Parliament and the Council, which banned the imports of products derived from animals fed by-products derived from animals of the same species. 
According to Block Jr. (2002), several methods have been proposed for the identification of animal byproducts in animal feeds, including DNA hybridization, ELISA, and PCR. Also, mass spectrometry, analyzing isotope ratios of the chemical element carbon, has been successfully applied to test the authenticity and quality of food products, such as fruit juice (Bricout \& Koziet, 1987), wine (Martin et al., 1988), dairy products (Rossmann et al., 2000; Manca et al., 2001), and vegetable oils (Kelly et al., 1997).

Plant species with different photosynthesis cycles $\left(C_{3}\right.$ and $\left.C_{4}\right)$ present different carbon isotope ratios $\left({ }^{13} \mathrm{C} /{ }^{12} \mathrm{C}\right)$, and these natural differences allow their use as markers in animal feeds. The advantages of this method is that it does not change animal natural conditions, no specifically marked compounds need to be synthesized, and particularly, human health and environmental safety issues associated to the use of radioactive isotopes are prevented (Jones et al., 1979; Tieszen, 1978; Tyrrell et al., 1984; Boutton et al., 1988; Metges et al., 1990). The utilization of stable isotopes as markers in different poultry tissues allows estimating the rate of replacement of tissue stable isotopes by those derived from the diet (Denadai et al., 2007; Gottmann et al., 2008; Pelícia et al., 2011; Araujo et al., 2011).

Carbon isotope ratios $\left({ }^{13} \mathrm{C} /{ }^{12} \mathrm{C}\right)$ combined with nitrogen isotope ratios $\left({ }^{15} \mathrm{~N} /{ }^{14} \mathrm{~N}\right)$ in the final product allow tracing the inclusion of animal by-product meals in broiler (Carrijo et al., 2006; Gottmann et al., 2008; Oliveira, 2010), layer (Denadai et al., 2008), and quail (Móri et al., 2007) feeds. However, this technique had not been employed yet in studies with poultry reared for long periods, where theoretically animal by-products could be included and withdrawn from the feeds without being detected by this method. Meat-type quails were used as a model in the present study because they are small and have low feed intake, and therefore, lower production cost and easier management.

The objective of the present study was to trace the inclusion of poultry offal meal (POM) in the diet and its subsequent replacement by a vegetable diet in meattype quails reared for a long period using the technique of stable isotopes.

\section{MATERIALS AND METHODS}

The experiment was carried out at the facilities of the Poultry Nutrition Laboratory of the School of Veterinary Medicine and Animal Science, UNESP, Botucatu campus, Brazil, between April 10 and August 13, 2007, totaling 126 experimental days.
One-day-old quails $(n=320)$ were housed in 16 $(0.30 \mathrm{~m} \times 0.95 \mathrm{~m} \times 0.50 \mathrm{~m})$ cages at a density of 20 birds per cage, totaling 40 birds per treatment.

Each cage was initially equipped with mini cup drinkers and tray feeders. On day 21, this equipment was replaced by nipple drinkers and trough feeders. Birds were offered water and feed ad libitum during the entire experimental period.

A 24-h light lighting program was adopted during the first three weeks, using $100 \mathrm{~W}$ incandescent bulbs, and thereafter, natural light was used.

Quails were randomly distributed into eight treatments: a vegetable diet (T1) based on corn and soybean meal, and a diet containing 8\% POM were fed until the end of the experimental period (T2) or replaced by the vegetable diet on days 42 (T3), 56 (T4), 70 (T5), 84 (T6), 98 (T7), and 112 (T8) of the experimental period.

Feeds were formulated to supply quails' nutritional requirements. A commercial two-phase feeding schedule was adopted: starter (1-21 days of age) and grower (22-126 days of age). The experimental diets were based on corn and soybean meal and formulated to contain equal energy and protein levels (Table 1).

Four birds per treatment (one per replicate) were randomly selected and sacrificed by neck dislocation to collect Pectoralis major muscle samples per sampling period. Birds were sacrificed at 14-d intervals, that is on the days the POM-containing diet was changed to the vegetable diet (days 42, 56, 70, 84, 98, 112, and 126).

Samples were prepared according to Oliveira (2010) and Móri et al. (2007, 2008), placed in duly identified plastic bags and immediately frozen at $-20^{\circ} \mathrm{C}$ for subsequent isotope analyses. Samples were dried in force-ventilation oven at $65^{\circ} \mathrm{C}$ and then ground in freeze-mill until a very fine particle size homogenous material was obtained.

Isotopic analyses were conducted at the Environmental Stable Isotopes Center, Biosciences Institute (CIE/IB), UNESP, Botucatu campus, according to Oliveira (2006), Móri et al. (2007, 2008), Denadai et al. (2008) and Gottmann et al. (2008). In tin capsules, approximately $100 \mu \mathrm{g}$ and $400 \mu \mathrm{g}$ of sample were weighed for carbon and nitrogen analyses, respectively.

In order to determine carbon $\left({ }^{13} \mathrm{C} /{ }^{12} \mathrm{C}\right)$ and nitrogen $\left({ }^{15} \mathrm{~N} /{ }^{14} \mathrm{~N}\right)$ isotopic ratios, an isotopic ratio mass spectrometer (IRMS - DELTA-S, FINNIGAN MAT) coupled to an Elemental Analyzer (EA 1108 CHN) was used, according to the method described by Ducatti et al. (2004). 
Table 1 - Feedstuff composition, calculated nutritional levels, and mean isotope values of the starter (1-21 d) and grower (22-126 d) experimental diets.

\section{Experimental diets}

Ingredients (\%)

Starter

Grower

\begin{tabular}{|c|c|c|c|c|}
\hline & Vegetable & $8 \%$ РОM $^{1}$ & Vegetable & $8 \%$ POM $^{1}$ \\
\hline Ground corn & 44.96 & 50.69 & 50.94 & 58.19 \\
\hline Soybean meal & 48.50 & 37.29 & 40.82 & 29.26 \\
\hline Poultry offal meal & - & 8.00 & - & 8.00 \\
\hline Crude soybean oil & 2.87 & 0.90 & 4.82 & 2.34 \\
\hline Calcitic limestone & 1.02 & 0.88 & 0.92 & 0.77 \\
\hline Dicalcium phosphate & 1.80 & 0.74 & 1.66 & 0.60 \\
\hline DL-Methionine & 0.10 & 0.07 & 0.09 & 0.06 \\
\hline L-lysine & - & - & - & 0.03 \\
\hline Mineral and vitamin supplement & $0.40^{2}$ & $0.40^{2}$ & $0.40^{3}$ & $0.40^{3}$ \\
\hline Salt & 0.35 & 0.35 & 0.35 & 0.35 \\
\hline Inert material (kaolin) & - & 0.68 & - & - \\
\hline Total & 100.00 & 100.00 & 100.00 & 100.00 \\
\hline \multicolumn{5}{|l|}{ Calculated nutritional levels } \\
\hline Metabolizable energy, kcal/kg & 2900 & 2900 & 3100 & 3100 \\
\hline Crude protein, \% & 26.00 & 26.00 & 23.00 & 23.00 \\
\hline Calcium, \% & 1.00 & 1.00 & 0.90 & 0.90 \\
\hline Available phosphorus, \% & 0.45 & 0.45 & 0.42 & 0.42 \\
\hline Methionine, \% & 0.44 & 0.49 & 0.44 & 0.44 \\
\hline Methionine + cystine, \% & 0.90 & 0.90 & 0.81 & 0.81 \\
\hline Lysine, \% & 1.40 & 1.45 & 1.29 & 1.26 \\
\hline \multicolumn{5}{|l|}{ Analyzed mean isotope values ${ }^{4}$} \\
\hline$\delta{ }^{13} \mathrm{C}$ & -19.48 & -18.53 & -19.17 & -17.44 \\
\hline$\delta{ }^{15} \mathrm{~N}$ & 1.34 & 2.26 & 1.88 & 2.45 \\
\hline
\end{tabular}

1 POM = poultry offal meal. 2 Vitamin and mineral supplement (Nutronâ) for the starter phase per kg product: $\mathrm{Mn}=18,750 \mathrm{mg} ; \mathrm{Zn}=17,500 \mathrm{mg} ; \mathrm{Fe}=11,50 \mathrm{mg} ; \mathrm{Cu}=$ 2,000mg; I = 187.5mg; Se = 75mg; Vit. A = 1,680,00IU/kg; Vit. D3 = 400,000IU/kg;Vit. E =3,500mg; Vit. K3 = 360mg; Vit. B1 = 436.5mg; Vit. B2 = 1,200mg; Vit. B6 = $624 \mathrm{mg}$; Vit. B12 = 2,400mcg; folic acid = 200mg; pantothenic acid = 3,120mg; niacin = 8,400mg; biotin = 10mg; choline = 75.700mg; coccidiostat = 25,000mg; growth promoter $=20,000 \mathrm{mg} .3$ Vitamin and mineral supplement (Nutronâ) for the grower phase per kg product: $\mathrm{Mn}=18,750 \mathrm{mg} ; \mathrm{Zn}=17,500 \mathrm{mg} ; \mathrm{Fe}=11,250 \mathrm{mg} ; \mathrm{Cu}=2,000 \mathrm{mg} ; \mathrm{I}$ $=187,5 \mathrm{mg} ; \mathrm{Se}=75 \mathrm{mg} ;$ Vit. A = 1,400,00IU/kg; Vit. D3 = 300,000IU/kg; Vit. E =2,500mg; Vit. K3 = 300mg; Vit. B1 = 388mg; Vit. B2 = 1,000mg; Vit. B6 = 520mg; Vit. B12 = 2,000 mcg; folic acid $=162.5 \mathrm{mg}$; pantothenic acid $=2,600 \mathrm{mg}$; niacin $=7,000 \mathrm{mg}$; choline $=65,250 \mathrm{mg}$; coccidiostat $=15,000 \mathrm{mg}$; growth promoter $=20,000 \mathrm{mg} .4$ Mean isotope values expressed as d $13 \mathrm{C}$ relative to the Peedee Belemnite standard (PDB) and d 15N relative to atmospheric N2 standard.

The results of the analyses were expressed in delta ( $\delta$ ) per thousand of the sample isotope ratio relative to the international standards Peedee Belemnite (PDB) and atmospheric nitrogen $\left(\mathrm{N}_{2}\right)$ for the elements carbon and nitrogen, respectively, according to the expression:

$\delta X_{(\text {sample, standard) }}=\left[\left(R_{\text {sample }} / R_{\text {standard }}\right)-1\right] \times 10^{3}$
Where:

$\delta X=$ enrichment of the heaviest isotope of the chemical element $X$ of the sample relative to the respective international standard.

$\mathrm{R}=$ ratio between the least and the most abundant isotope (13C/12C and 15N/14N). 
Sernagiotto ER, Ducatti C, Sartori JR, Stradiotti AC, Maruno MK, Araujo PC, Carvalho FB, Pezzato AC

The obtained isotope results were submitted to multivariate analysis of variance (MANOVA) with the aid of the GLM procedure of SAS (2002) statistical program. Based on the data generated by error matrices, 95\% confidence regions were determined to detect possible isotope differences $\left(\delta^{13} \mathrm{C}\right.$ and $\left.\delta^{15} \mathrm{~N}\right)$ between the vegetable treatment (T1) and treatments with POM inclusion during different times of the rearing period $(\mathrm{T} 2, \mathrm{~T} 3, \mathrm{~T} 4, \mathrm{~T} 5, \mathrm{~T} 6, \mathrm{~T} 7, \mathrm{~T} 8)$.

In order to be considered different from the T1 (vegetable diet), the confidence region of any determined treatment cannot overlap any axis of the graph. When an ellipse overlaps one of the axes, the $\delta{ }^{13} \mathrm{C}$ and $\delta{ }^{15} \mathrm{~N}$ differences among treatment means is equal to zero, and therefore, there are no differences among the evaluated treatments ( $p>0.05)$.

\section{RESULTS AND DISCUSSION}

The $\delta^{13} \mathrm{C}$ and $\delta^{15} \mathrm{~N}$ isotope results of the breast muscle of meat-type quails obtained in the present study are shown in Table 2 , and the ellipses generated
The Use of Carbon and Nitrogen Stable Isotopes for the Detection of Poultry Offal Meal in Meat-Type Quail Feeds

from the data obtained in the statistical analysis are presented in Figure 1.

Both $\delta^{13} \mathrm{C}$ and $\delta^{15} \mathrm{~N}$ isotope enrichment of the breast muscle was detected in birds that were fed the diets containing POM sometime during the rearing period. This ${ }^{13} \mathrm{C}$ and ${ }^{15} \mathrm{~N}$ enrichment when poultry were fed animal by-product meals was also observed by Oliveira (2010), Carrijo et al. (2006), Móri et al. (2007, 2008), Denadai et al. (2008) and Gottmann et al. (2008).

According to DeNiro \& Epstein (1976, 1978), the isotope values of animal meals used as feedstuffs reflect the isotope signal of the animal from which they derive, and are $\pm 2 \%$ for $\delta^{13} \mathrm{C}$ and $\pm 3 \%$ for $\delta^{15} \mathrm{~N}$, thereby allowing the detection of the inclusion of poultry offal meal in the feed of meat-type quails.

The longer ellipses in Figure 1 indicate that the amplitude of the points generated by the error matrix was wider, possibly due to the high standard deviations observed. According to Murakami \& Ariki (1998), Garcia \& Pizzolante (2004) and Móri et al. (2007), higher than expected standard deviations are

\begin{tabular}{|c|c|c|c|c|c|c|c|c|}
\hline \multirow{2}{*}{\multicolumn{2}{|c|}{ Treatamentos1 }} & \multicolumn{7}{|c|}{ Time of sacrifice (days) } \\
\hline & & \multirow{2}{*}{$\frac{42}{-20.64 \pm 0.48}$} & \multirow{2}{*}{$\frac{56}{-21.43 \pm 0.40}$} & \multirow{2}{*}{$\frac{70}{-21.53 \pm 018}$} & \multirow{2}{*}{$\frac{84}{-21.32 \pm 0.43}$} & \multirow{2}{*}{$\frac{98}{-21.70 \pm 0.31}$} & \multirow{2}{*}{$\frac{112}{-21.81 \pm 0.13}$} & \multirow{2}{*}{$\frac{126}{-21.20 \pm 0.29}$} \\
\hline$T_{1}$ & $\delta 13 C$ & & & & & & & \\
\hline TI & $\delta 15 \mathrm{~N}$ & $3.03 \pm 0.06$ & $3.00 \pm 0.20$ & $2.99 \pm 0.09$ & $3.09 \pm 0.15$ & $3.13 \pm 0.12$ & $3.28 \pm 0.13$ & $3.44 \pm 0.27$ \\
\hline \multirow{2}{*}{$\mathrm{T} 2$} & $\delta 13 C$ & $-19.43 \pm 0.38$ & $-19.37 \pm 0.36$ & $-19.90 \pm 0.13$ & $-19.86 \pm 0.17$ & $-19.94 \pm 0.20$ & $-20.13 \pm 0.43$ & $-19.34 \pm 0.29$ \\
\hline & $\delta 15 \mathrm{~N}$ & $3.54 \pm 0.08$ & $3.78 \pm 0.20$ & $3.89 \pm 0.16$ & $3.99 \pm 0.09$ & $3.77 \pm 0.12$ & $3.80 \pm 0.19$ & $4.49 \pm 0.29$ \\
\hline \multirow{2}{*}{ T3 } & $\delta 13 C$ & & $-20.34 \pm 0.37$ & $-20.74 \pm 0.35$ & $-20.99 \pm 0.19$ & $-21.42 \pm 0.26$ & $-21.47 \pm 0.04$ & $-21.32 \pm 0.08$ \\
\hline & $\delta 15 \mathrm{~N}$ & & $3.40 \pm 0.24$ & $3.01 \pm 0.20$ & $3.14 \pm 0.15$ & $3.14 \pm 0.07$ & $3.28 \pm 0.04$ & $3.88 \pm 0.55$ \\
\hline \multirow{2}{*}{ T4 } & $\delta 13 C$ & & & $-20.61 \pm 0.34$ & $-20.93 \pm 0.23$ & $-21.37 \pm 0.18$ & $-21.56 \pm 0.36$ & $-20.61 \pm 0.34$ \\
\hline & $\delta 15 \mathrm{~N}$ & & & $3.53 \pm 0.07$ & $3.46 \pm 0.15$ & $3.39 \pm 0.08$ & $3.32 \pm 0.11$ & $4.33 \pm 0.14$ \\
\hline \multirow{2}{*}{ T5 } & $\delta 13 C$ & & & & $-20.60 \pm 0.07$ & $-20.89 \pm 0.23$ & $-20.91 \pm 0.23$ & $-21.28 \pm 0.28$ \\
\hline & $\delta 15 \mathrm{~N}$ & & & & $3.40 \pm 0.09$ & $3.49 \pm 0.16$ & $3.34 \pm 0.28$ & $3.62 \pm 0.25$ \\
\hline \multirow{2}{*}{ T6 } & $\delta 13 C$ & & & & & $-20.66 \pm 0.36$ & $-21.26 \pm 0.08$ & $-20.93 \pm 0.27$ \\
\hline & $\delta 15 \mathrm{~N}$ & & & & & $3.70 \pm 0.18$ & $3.38 \pm 0.08$ & $4.05 \pm 0.23$ \\
\hline \multirow{2}{*}{$\mathrm{T7}$} & $\delta 13 C$ & & & & & & $-20.41 \pm 0.26$ & $-20.99 \pm 0.10$ \\
\hline & $\delta 15 \mathrm{~N}$ & & & & & & $3.53 \pm 0.16$ & $3.48 \pm 0.10$ \\
\hline \multirow{2}{*}{ T8 } & $\delta 13 C$ & & & & & & & $-20.51 \pm 0.24$ \\
\hline & $\delta 15 \mathrm{~N}$ & & & & & & & $4.49 \pm 0.21$ \\
\hline
\end{tabular}

1T1: diet based on corn and soybean meal until d 126; T2: diet with 8\% poultry offal meal inclusion (POM) until d 126; T3: diet with 8\% POM inclusion until d 42, and T1 diet thereafter; T4: diet with 8\% POM inclusion until d 56, and T1 diet thereafter; T5: diet with 8\% POM inclusion until d 70, and T1 diet thereafter; T6: diet with 8\% POM inclusion until d 84, and T1 diet thereafter; T7: diet with 8\% POM inclusion until d 98, and T1 diet thereafter; T8: diet with 8\% POM inclusion until d 112, and T1 diet thereafter. 

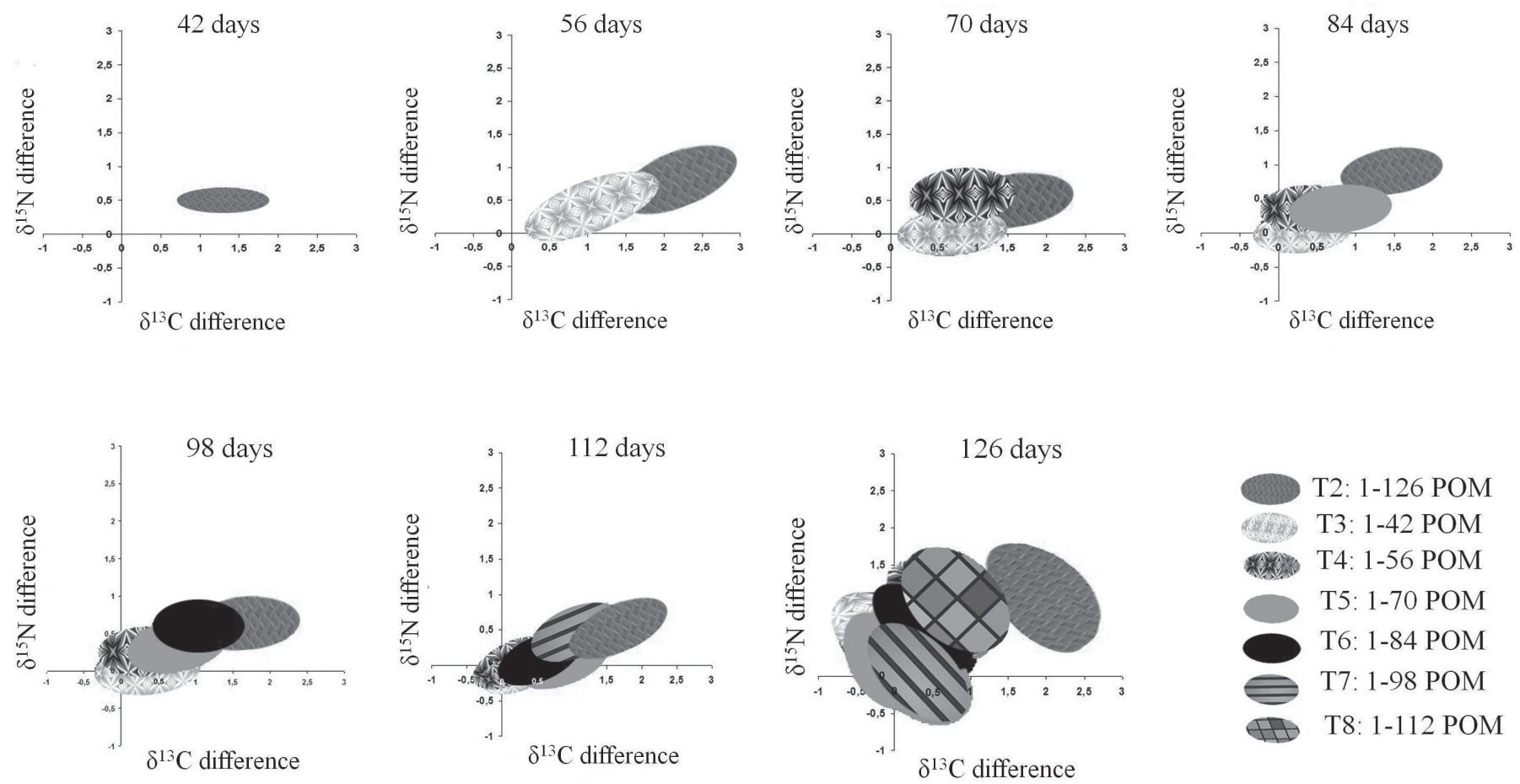

Figure 1 - Confidence regions 1 of d $13 \mathrm{C}$ and d $15 \mathrm{~N}$ values in the breast muscle of meat-type quails fed poultry offal meal compared with those of quails fed the purely vegetable diet (T1), according to day of sacrifice.

${ }^{1}$ Overlapping ellipses representing the treatments are not different $(p>0.05)$.

frequent in meat-type quails, as these birds have not been submitted to significant genetic improvement.

Differences in $\delta^{15} \mathrm{~N}$ between birds fed POM sometime during the rearing period and those fed only the vegetable diet (T1) were lower than $\delta^{13} \mathrm{C}$ differences, placing confidence regions closer to the carbon axis than to the nitrogen axis. According to Oliveira (2010), this behavior is due to the carbon and nitrogen isotope differences between the vegetable diet and that containing poultry offal meal.

Figure 1 shows that T2 was different from T1 on all evaluation days. This is attributed to the fact that T1 birds were fed the vegetable diet and T2 the diet with POM inclusion, both for the entire rearing period. The different isotope signals of these diets allowed differentiating the treatments by the use of the breast muscle, in agreement with Móri et al. (2007, 2008). However, T3 birds were not significantly different from the vegetable-diet treatment (T1). T1 was different from T4 between $\mathrm{d} 56$ and 70, from T5 between $\mathrm{d} 70$ and 84, from T6 between $d 84$ and 98, and from T7 between $\mathrm{d} 98$ and 112, and from T8 between $\mathrm{d} 112$ and 126.

The treatments with the dietary inclusion of POM were different from the vegetable treatment $(\mathrm{T} 1)$ when birds were sacrificed two weeks after the diet was changed, and thereafter presented similar behavior to T1, except for T3, which was similar to T1 14 days after the diet was changes, and for T2, which was different from $\mathrm{T} 1$ at all evaluated times.

It was possible to trace POM in the breast muscle when the diet was changed to the vegetable diet two weeks before sacrifice possibly because the growth curve of the experimental birds was close to the stabilization of the isotope signal. Therefore, their metabolism was probably slower than that of the broilers evaluated by Oliveira (2010), which presented similar isotope signal 14 days after the change of a diet containing poultry offal meal to a vegetable diet.

However, Oliveira (2010) found that dietary POM can be detected in the keel and the tibiotarsus two weeks after the diet is changed to a purely vegetable diet.

Considering these differences among tissues, further studies are needed to evaluate the possibility of tracing dietary poultry offal meal at different inclusion levels and using tissues with slower metabolism.

\section{CONCLUSIONS}

The use of the technique of carbon and nitrogen stable isotopes for tracing poultry offal meal inclusion 
in the diet of meat-type quails reared for a long period can only detect its total absence in the breast muscle for intervals longer than 14 days of feeding.

\section{REFERENCES}

Araujo PC, Sartori JR, Cruz VC, Pezzato AC, Ducatti C, Stradiotti AC, Pelicia VC. Rastreabilidade de farinha de vísceras de aves por isótopos estáveis em penas de frangos de corte. Pesquisa Agropecuária Brasileira 2011;46(5):538-545

Baumgartner J. Japanese quail production, breeding and genetics. Word's Poultry Science 1994;50(3):227-235

Bertechini AG. Situação atual e perspectivas para a coturnicultura no Brasil [citado 2011 Dez 18]. Disponível em: http://aviculturaindustrial.com.br/ PortalGessulli/AppFile/codorna.

Block Junior C. Monitoramento da qualidade de rações brasileiras para ruminantes por espectrometria de massa.Simpósio Sobre Manejo e Nutrição de Aves e Suínos e tecnologia da produção de rações; 2002; Campinas, São Paulo. Brasil. p.251-252.

Boutton TW, Tyrrell HF, Patterson BW. Carbon kinetics of milk formation in Holstein cows in late lactation. Journal of Animal Science 1988;66:2636-2645

Bricout J, Koziet J. Control of the authenticity of orange juice by isotopic analysis. Journal of Agricultural Food Chemistry 1987;35:758-760.

Carrijo AS, Pezzato AC, Ducatti C, Sartori JR, Trinca L, Silva ET. Traceability of bovine meat and bone meal in poultry by stable isotope analysis. Revista Brasileira de Ciência Avícola 2006;8:37-42.

Denadai JC, Ducatti C, Pezzato AC, Carrijo AS, Caldara FR, Oliveira RP. Studies on carbono-13 turnover in eggs and blood of commercial layers. Brazilian Journal of Poultry Science 2007;8:251-256.

Denadai JC, Ducatti C, Sartori JR, Pezzato AC, Móri C, Gottmann R, Mituo $\mathrm{MAO}$, Bordinhon AM. The traceability of animal meals in layer diets as detected by stable carbon and nitrogen isotope analysis of eggs. Brazilian Journal of Poultry Science 2008; 10:189-194.

DeNiro MJ, Epstein S. Influence of diet on the distribution of carbon isotopes in animals. Geochimica et Cosmochimica Acta 1978; 42:495-506.

DeNiro MJ, Epstein S. You are what you eat (plus a few \%o) the carbon isotope cycle in food chains. Geological Society of America 1976;6:834.

Ducatti C. Isótopos estáveis ambientais [apostila]. Botucatu (SP): Instituto de Biociências, Universidade Estadual Paulista; 2004; p.184

Garcia EA, Pizzolante CC. Nutrição de codornas para posturas. 2th Simpósio Internacional e 1th Congresso Brasileiro de Coturnicultura; 2004; Lavras, Minas Gerais. Brasil. p.65-74.

González-Martin I, González-Pérez C, Hernández-Méndez J, MarquésMacias E, Sanz-Poveda F. Use of isotope analysis to characterize meat from Iberian-breed swine. Meat Science 1999;52:437-441.

Gottmann R, Pezzato AC, Ducatti C, Denadai JC, Mituo MAO, Móri C, Sartori JR. 2008. Rastreabilidade de subprodutos de origem animal em dietas com levedura e trigo para frangos. Pesquisa Agropecuária Brasileira 2008; 43(12):1641-1647.

Jones R, Ludlow M, Troughton J. Estimation of the proportion of $\mathrm{C}_{3}$ and $\mathrm{C}_{4}$ plant species in diet of animals from the ratio of natural ${ }^{12} \mathrm{C}$ and ${ }^{13} \mathrm{C}$ isotopes in the faeces. Journal of Agricultural Science 1979; 92:91100.
Kelly S, Parker I, Sharman M, Dennis J, Goodall I. Assessing the authenticity of single seed vegetable oils using fatty acid stable carbon isotope ratios $\left({ }^{13} \mathrm{C} /{ }^{12} \mathrm{C}\right)$. Food Chemistry 1997;59(2):181-186.

Manca G, Carmin F, Coloru GC, Del Caro A, Depentori D, Franco MA, Versini G. Characterization of the geographical origin of Pecorino Sardo cheese by casein stable isotope $\left({ }^{13} \mathrm{C} /{ }^{12} \mathrm{C}\right.$ and $\left.{ }^{15} \mathrm{~N} /{ }^{14} \mathrm{~N}\right)$ ration and free amino acid ratios. Journal of Agricultural and Food Chemistry 2001;49:1404-1409.

Martin GJ, Guillou C, Martin ML, Cabanis MT, Tep Y, Aery J. Natural factors of isotope fractionation and the characterization of wines. Journal of Agricultural and Food Chemistry 1988;36:316-322

Metges C, Kempe K, Schimidt HL. Dependence of the carbon isotope contents of breath carbon dioxide, milk, serum and rumen fermentation products on the delta ${ }^{13} \mathrm{C}$ value of food in dairy cows. British Journal of Nutrition 1990; 63:187-196.

Móri C, Garcia EA, Ducatti C, Denadai JC, Pelícia K, Gottmann R, Mituo MAO, Bordinhon AM. Traceability of Animal Byproducts in Quail (Coturnix coturnix japonica) Tissues using Carbon $\left({ }^{13} \mathrm{C} /{ }^{12} \mathrm{C}\right.$ ) and Nitrogen $\left({ }^{15} \mathrm{~N} /{ }^{14} \mathrm{~N}\right)$ Stable Isotopes. Brazilian Journal of Poultry Science 2007;9(4):263-269

Móri C, Garcia EA, Ducatti C, Denadai JC, Gottmann R, Mituo MAO. Poultry Offal Meal Traceability in Meat Quail Tissues using the Technique of Stable Carbon $\left({ }^{13} \mathrm{C} /{ }^{12} \mathrm{C}\right)$ and Nitrogen $\left({ }^{15} \mathrm{~N} /{ }^{14} \mathrm{~N}\right)$ Isotopes. Brazilian Journal of Poultry Science 2008;10(1):45-52.

Murakami AE, Ariki J. Produção de codornas japonesas, Jaboticabal: FUNEP; 1998. p. 79.

Oliveira RP, Ducatti C, Pezzato AC, Denadai JC, Cruz VC, Sartori JR, Carrijo AS, Caldara FR. Traceability of poultry offal meal in broiler feeding using isotopic analysis $\left(\delta^{13} \mathrm{C}\right.$ and $\left.\delta^{15} \mathrm{~N}\right)$ of different tissues. Revista Brasileira de Ciência Avícola 2010;12(1):13-20.

Pelícia VC, Zavarize KC, Ducatti C, Stradiotti AC, Pezzato AC, Araujo PC, Mituo MAO, Madeira LA, Sartori JR. Nucleotídeos na dieta de frangos de corte e seus efeitos sobre a taxa de turnover da mucosa intestinal antes e após lesões causadas por coccidiose. Ciência Rural 2011:41(9):1652-1659.

Rossmann A, Haberhauer G, Holzl S, Horn P, Pichlmayer F, Voerkelius S. The potential of multielement stable isotope analysis for regional origin assignment of butter. European Food Research \& Technology 2000:211:32-40.

SAS Institute. SAS user's guide for windows enviroment. 9.1 version. Cary; 2002.

Tieszen L L. Carbon isotope fractionation in biological material. Nature 1978; 276:97-98

Tyrrell HF, Pelletier G, Chevalier R, Hillaire-Marcel C, Gagnon M. Use of carbon 13 as tracer in metabolism studies. Canadian Journal of Animal Science 1984;(Suppl 64):127-129. 